\title{
OPEN Eruca sativa seed napin structural insights and thorough functional characterization
}

\author{
Binish Khaliq ${ }^{1,2}$, Sven Falke ${ }^{3}$, Qamar Saeed ${ }^{4}$, Muhammad Bilal ${ }^{5}$, Aisha Munawar ${ }^{6}$, Arslan Ali ${ }^{7}$, \\ Gunnar Baermann ${ }^{8}$, Habib-ur-Rehman Athar ${ }^{1}$, Seema Mahmood ${ }^{1}$, Christian Betzel ${ }^{3}$, \\ Qurban $\mathrm{Ali}^{2 \bowtie}$ \& Ahmed Akrem ${ }^{1 \bowtie}$
}

A potent napin protein has been thoroughly characterized from seeds of rocket salad (Eruca sativa). Eruca sativa napin (EsNap) was purified by ammonium sulfate precipitation $(70 \%)$ and size-exclusion chromatography. Single intact $16 \mathrm{kDa}$ EsNap band was reduced to 11 and $5 \mathrm{kDa}$ bands respectively on SDS-PAGE. Nano LC-MS/MS yielded two fragments comprising of 26 residues which showed $100 \%$ sequence identity with napin-3 of Brassica napus. CD spectroscopy indicated a dominant $\alpha$-helical structure of EsNap. Monodispersity of EsNap was verified by dynamic light scattering, which also confirmed the monomeric status with a corresponding hydrodynamic radius of $2.4 \pm 0.2 \mathrm{~nm}$. An elongated ab initio shape of $E s N$ ap was calculated based on SAXS data, with an $R_{g}$ of $1.96 \pm 0.1 \mathrm{~nm}$. The ab initio model calculated by DAMMIF with P1 symmetry and a volume of approx. $31,100 \mathrm{~nm}^{3}$, which corresponded to a molecular weight of approximately $15.5 \mathrm{kDa}$. The comparison of the SAXS and $a b$ initio modeling showed a minimized $\chi^{2}$-value of 1.87 , confirming a similar molecular structure. A homology model was predicted using the coordinate information of Brassica napus rproBnlb (PDB ID: 1SM7). EsNap exhibited strong antifungal activity by significantly inhibiting the growth of Fusarium graminearum. EsNap also showed cytotoxicity against the hepatic cell line Huh7 and the obtained $\mathrm{IC}_{50}$ value was $20.49 \mu \mathrm{M}$. Further, strong entomotoxic activity was experienced against different life stages of stored grain insect pest $T$. castaneum. The result of this study shows insights that can be used in developing potential antifungal, anti-cancerous and insect resistance agents in the future using EsNap from E. sativa.

Plants are facing various pathogenic organisms in their environment, i.e. bacteria, fungi and insects. As a result plants can produce a large variety of antimicrobial compounds such as phytoalexins and proteins $s^{1,2}$. In particular, plants protect themselves by secretion of small antimicrobial or antifungal proteins such as lipid transfer proteins $^{3}$, snakins ${ }^{4}$, plant defensins ${ }^{5}$, hevein-like peptides ${ }^{6}$, glycine-rich peptides and napins ${ }^{7}$. Napin $(2 \mathrm{~S}$ albumin) is a low molecular mass protein present in Brassicaceae oilseed and belongs to the prolamin superfamily ${ }^{8}$. Among Brassicaceae seed storage proteins (SSPs), napin is the second most abundant protein after cruciferin and constitutes approx. $15-45 \%$ of all SSPs, depending on the specific species.

Brassica napus napins are heterodimers consisting of two polypeptides ${ }^{9}$ bridged through inter-chain covalent disulfide linkages ${ }^{10}$. Molecular structure determinations of napins revealed that disulfide bonds formed by cysteine residues play a crucial role. Cysteine residues are considered as conserved features of napins, due to their location and number in the polypeptide chain. There are eight cysteine amino acids, together called "eight Cys motif", that have been pinpointed in different Napin isoforms; six in the long chain and two in the short chain". Antimicrobial proteins of plants can be used to treat antibiotic-resistant microorganisms ${ }^{11}$. Further, plant-derived

\footnotetext{
${ }^{1}$ Botany Division, Institute of Pure and Applied Biology, Bahauddin Zakariya University, Multan, Pakistan. ${ }^{2}$ Botany Division Institute of Molecular Biology and Biotechnology, The University of Lahore, Lahore, Pakistan. ${ }^{3}$ Laboratory for Structural Biology of Infection and Inflammation, The Hamburg Centre for Ultrafast Imaging, University of Hamburg, c/o DESY. Build. 22a, Notkestrasse 85, 22607 Hamburg, Germany. "Department of Entomology, Bahauddin Zakariya University, Multan, Pakistan. ${ }^{5}$ Centre for Applied Molecular Biology, University of Punjab, Lahore, Pakistan. ${ }^{6}$ Department of Chemistry, University of Engineering and Technology, G.T. Road, Lahore 54890, Pakistan. ${ }^{7}$ Dr. Panjwani Center for Molecular Medicine and Drug Research, International Center for Chemical and Biological Sciences, University of Karachi, Karachi, Pakistan. ${ }^{8}$ Molekulare Phytopathologie, Universität Hamburg, Biozentrum Klein Flottbek Ohnhorststr, 1822609 Hamburg, Germany. ${ }^{\boxplus}$ email: saim1692@gmail.com; ahmedakrem@bzu.edu.pk
} 
A

B
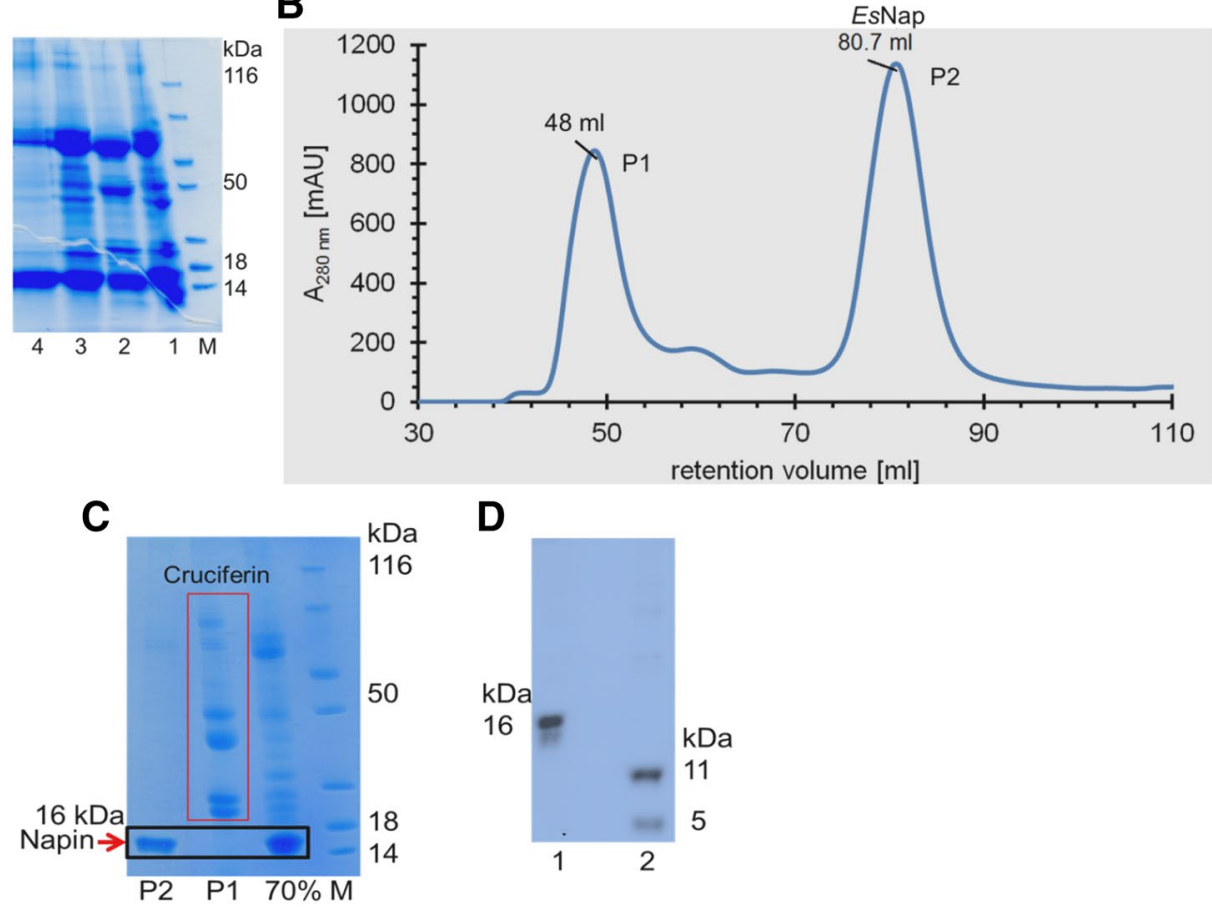

Figure 1. Purification and molecular weight determination of E. sativa seed napin (EsNap). (A) Partial purification of $E s \mathrm{Nap}$ from crude extract, lane 1; crude extract, lane 2 and 3; $50 \%$ ammonium sulfate saturation of crude extract supernatant, lane 4; re-dissolved and dialyzed 70\% ammonium sulfate saturation pellet, $\mathrm{M}$; Protein Ladder (Catalog, 22,610). (B) Purification of EsNap by calibrated size exclusion chromatography (SEC, HiLoad 16/60 Superdex 75) subsequent to ammonium sulfate precipitation (70\% saturated solution). Chromatogram showed the P1 and P2 with retention volume of 48 and $80.7 \mathrm{ml}$ respectively. (C) SDS-PAGE showed that P1 has cruciferin and EsNap was found in P2 of the chromatogram while lane 1 is the $70 \%$ solubilized pellet before SEC. (D) SDS-PAGE analysis of napin under non-reducing condition (lane 1) and in the presence of $20 \mathrm{mM}$ DTT (lane 2) which splitted the intact band into approximately 11 and $5 \mathrm{kDa}$ respectively.

antimicrobial compounds are of high clinical value for the treatment of bacterial infections and infections caused by several fungi as well ${ }^{12}$. Specifically, some napins possess cytotoxic effects, whereby they can be applied in the development of new anti-cancer drugs ${ }^{13}$. Napin genes are being used in the development of transgenic plants expressing higher levels of napins, making them more pathogen resistant supporting a reduction of yield losses in the agriculture sector ${ }^{14}$. In short, the promising bioactivities of napins make them suitable candidates to act against a number of human pathogens ${ }^{15,16}$.

Rocket Salad (Eruca sativa Miller), locally known as Taramira; is an annual herb and belongs to the family Brassicaceae (Cruciferae). It is grown in different parts of the Indo-Pak subcontinent and in the Middle East. Eruca sativa is a minor oil crop; widely used as culinary and for medicines as remedies for different diseases. There is only sporadic information available about phytochemistry and bioactivity of this oily crop ${ }^{17}$. The regular consumption of $E$. sativa has been associated with the prevention of cardiovascular diseases and reduction in cancer risk ${ }^{18,19}$. It is known to have diuretic and anti-inflammatory activities ${ }^{20}$. Eruca seeds possess various proteins, glucosinolates, vitamins $\mathrm{A}$ and $\mathrm{C}$, flavonoids, erucic acid and a relatively high oil content ${ }^{17,21}$. It is commonly used as animal feed in Asia, particularly in India and Pakistan. In view of its potential medicinal uses, it is hypothesized that Rocket Salad might have antimicrobial proteins/peptides in their seeds/leaves which can be exploited for the development of anti-cancerous drug after detailed understanding of its structure with subsequent characterization. Present study describes the structural insights and thorough functional characterization of a napin, which was identified and purified from seeds of E. sativa.

\section{Results}

Napin purification. Napin was precipitated by ammonium sulfate from the crude extract of Eruca sativa (Fig. 1A). Napin protein remained in supernatant after $50 \%(\mathrm{w} / \mathrm{v})\left(\mathrm{NH}_{4}\right)_{2} \mathrm{SO}_{4}$ saturation constant while subsequent $70 \%$ precipitated the protein in pellet. The dissolved pellet was extensively dialyzed to remove any further salt traces and subjected to size-exclusion chromatography to obtain the highly purified protein fractions. Ultimately, an optimized combination of ammonium sulfate precipitation along with chromatographic steps provided a $>95 \%$ pure napin solution from seeds of Eruca sativa, as judged by SDS-PAGE analysis. The gel filtration chromatogram showed two absorbance peaks and the corresponding SDS-PAGE showed that first peak contained high molecular weight cruciferins while EsNap was found in the second peak (Fig. 1B,C). EsNap fractions 


\begin{tabular}{|l|l|l|l|}
\hline Purification steps & Total protein $(\mathbf{m g})$ & Purification (times) & Recovery (\%) \\
\hline Crude extract & 80 & 1 & 100 \\
\hline Ammonium sulfate fractionation (50\% supernatant) & 54 & 1.48 & 67 \\
\hline Ammonium sulfate fractionation (70\% pellet) & 20 & 4 & 25 \\
\hline Hi Load 16/60 Superdex 200 column & 6 & 13 & 7.5 \\
\hline
\end{tabular}

Table 1. Purification steps of Eruca sativa Napin (EsNap) from one gram of seed powder.

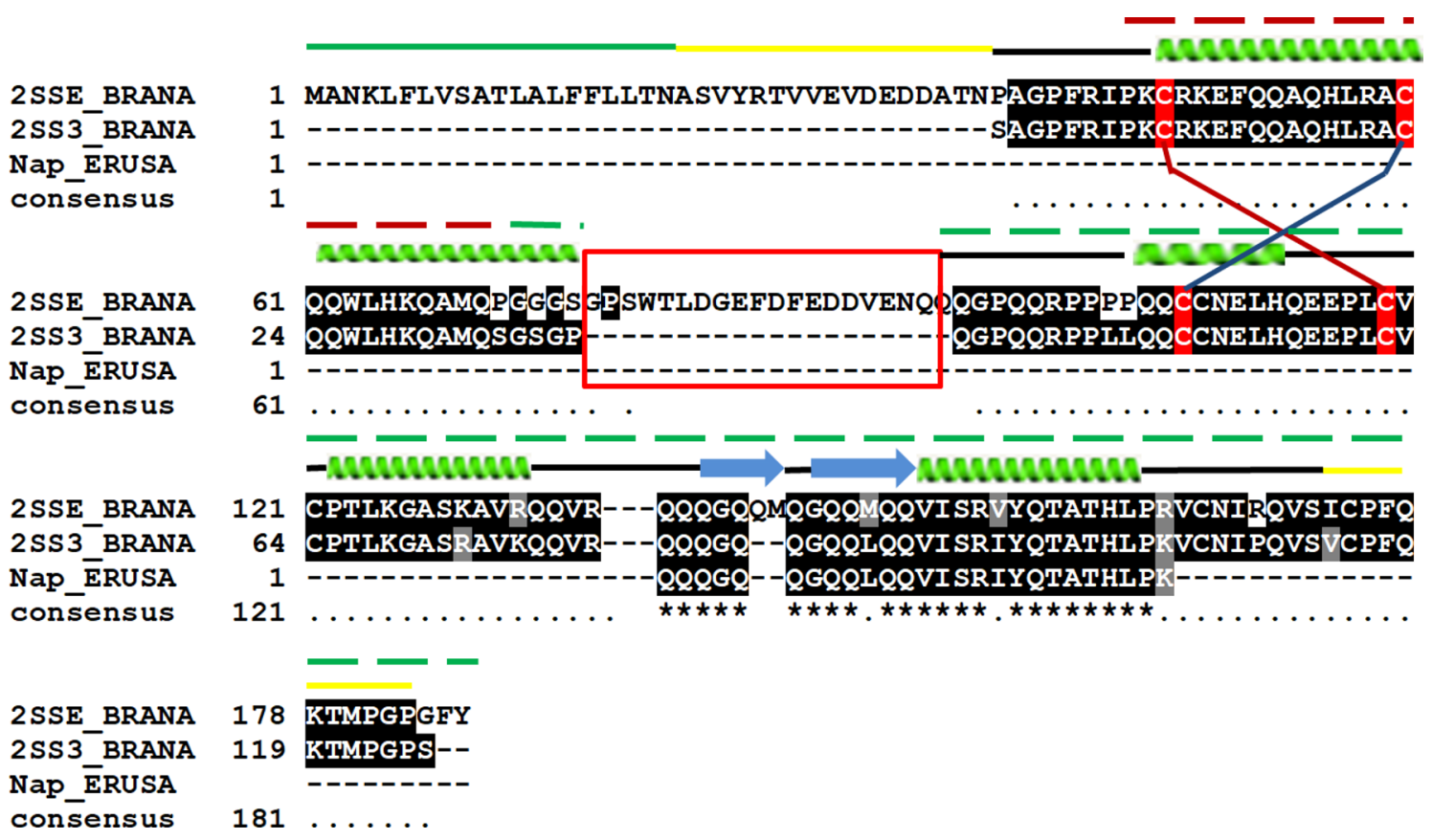

Figure 2. Multiple sequence alignment of EsNap with other closely related plant napins 2SS3_BRANA (Napin3: Brassica napus), 2SSE_BRANA (Napin embryo-specific: Brassica napus) and Nap_ERUSA (Napin: Eruca sativa). Secondary structure elements ( $\alpha$-helices and $\beta$-sheets) of EsNap are indicated at the top. Signal peptide, $\mathrm{N} / \mathrm{C}$ terminus and turns are indicated with green, yellow and black bars respectively. Identically conserved residues are labeled by asterisks $\left(^{*}\right)$, while semi-conserved substitutions are labeled by single dots (.) and cysteine involved in disulfide bonds between two chains are shown in red color. The highly flexible region is highlighted with a red box. Smaller and larger chains are shown in dot line (-) upper on the secondary structure elements in green and red color respectively Multiple sequences alignment was performed by using ClustalW in the default set up and BoxShade server.

with maximum purity were stored at $4{ }^{\circ} \mathrm{C}$. Further SDS-PAGE analysis showed the splitting of napin $(16 \mathrm{kDa})$ into two daughter fragments of 11 and $5 \mathrm{kDa}$ upon addition of DTT confirming the quaternary structure as well as the presence of inter-chain disulfide bonds within the structure (Fig. 1D). The purification strategy resulted in purification of 13 -fold with a $7.5 \%$ yield (Table 1 ) from one gram of E. sativa seed powder.

Proteinidentification. LC-MS/MSidentified twopeptides(IYQTATHLPK ${ }^{10}$,QQQGQQGQQLQQVISR ${ }^{16}$ ) (peak raw data is shown in Fig. S1: Supplementary material) which showed 100 and 85\% sequence identity with napin-3 (UniProtKB ID: P80208) and embryo-specific napin (UniProtKB ID: P09893) from Brassica napus, respectively. The fragmented sequence of EsNap was used for multiple sequence alignment with napin-3 and embryo-specific napin of Brassica napus (Fig. 2). The alignment analysis showed that EsNap is more identical to B. napus napin.

Isoelectric focusing (IEF) of EsNap. The result of isoelectric focusing showed that EsNap is basic protein and have the basic pI. A single band observed after isoelectric focusing (IEF) reveals the basic pI of 8.0, like other already reported napins from Brassicaceae species (Fig. S2: Supplementary material).

Secondary structure determination of EsNap. The circular dichroism (CD) spectrum (Fig. 3) showed predominantly $a$-helical structure, as indicated by two distinct ellipticity minima ${ }^{22}$, as well as some flexible loops. The CD spectrum corresponds to approx. 38\% a-helix, 9\% $\beta$-sheet, 19\% turn and 34\% random coil structure 


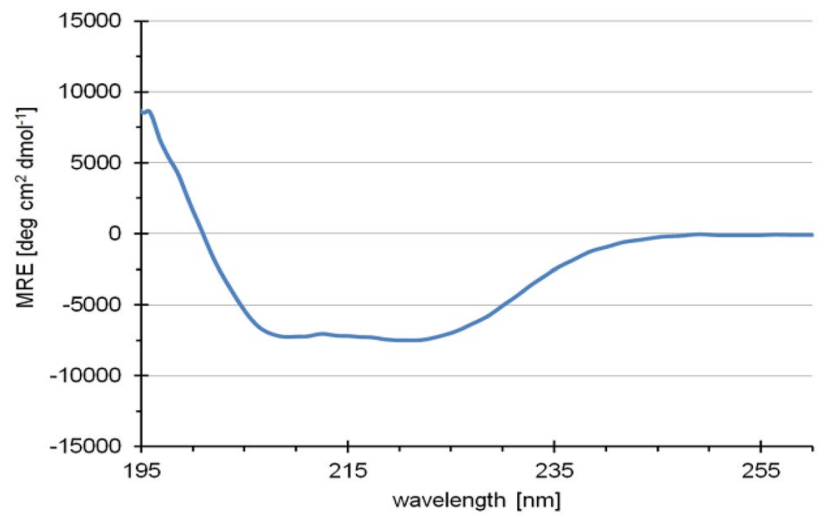

Figure 3. CD spectroscopy of EsNap. Far-UV CD spectrum of EsNap is indicating predominantly a-helical secondary structure $(38 \%)$.

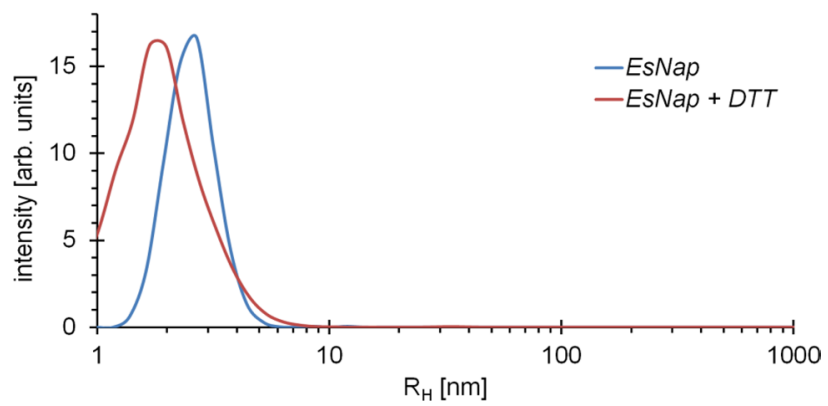

Figure 4. The particle size distribution obtained by dynamic light scattering reveals the monodispersity of the Es Nap solution (blue line) with a hydrodynamic radius of $2.4 \pm 0.2 \mathrm{~nm}$. A broadening and shift in hydrodynamic radius ( $1.8 \pm 0.2 \mathrm{~nm}$; red line) was observed after the addition of $20 \mathrm{mM}$ DTT to EsNap solution which confirmed the splitted banding pattern as already observed on SDS-PAGE under reduced conditions. Obtained results indicated that EsNap is a monomeric globular protein.

applying the software Secondary Structure Estimation (Jasco) and the algorithm according to Yang et al. for data interpretation ${ }^{23}$ and fit curve calculation.

DLS analysis and assessment of tertiary and quaternary structure by small-angle X-ray scattering. Monodispersity and homogeneity of EsNap solution was verified by applying DLS calculation. A hydrodynamic radius of $2.4 \pm 0.2 \mathrm{~nm}$ is (Fig. 4) indicating that the protein is monomeric in solution. The averaged scattering amplitudes of EsNap are indicating an $\mathrm{R}_{\mathrm{g}}$ of $1.96 \pm 0.01 \mathrm{~nm}$ according to the Guinier approximation determined by AUTORG, which is implemented in PRIMUS ${ }^{24}$. The $\mathrm{P}(\mathrm{R})$ function is indicative for an oblate particle with a maximum diameter of $5.6 \mathrm{~nm}$. According to the volume of correlation, the molecular weight of napin is approximately $16 \mathrm{kDa}$. Considering P1 symmetry of a monomer, an ab initio model was calculated using GASBOR, with a corresponding molecular weight of $15 \mathrm{kDa}$. The particle shape is rather oblate with extended $\mathrm{C}$ - and N-terminus that may harbor a certain degree of flexibility, as indicated by superimposition (Fig. 5). The molecular weight estimation based on SAXS data well supports complementary results of DLS and electrophoresis experiments.

EsNap homology modeling. The EsNap 3D model consists of a globular four-helix motif with up and down topology for the predicted structure where the first helix (H1) is not splitted into two helices like in rproB$\mathrm{nIb}$ and in rRicC3. Structures rproBnIb and rRicC3 have the five -helix from residues 3-11 (helix Ia), 16-25 (helix Ib), 44-54 (helix II), 57-71 (helix III), and 81-95 (helix IV) ${ }^{25}$. Two disulfide bridges (CYs10-Cys62 and Cys23-Cys51) are formed between the smaller and longer chains in Fig. 6(2A). H3 and H4 are almost antiparallel to each other and are connected by two short $\beta$-sheets, which are constituted by residues Gln76-Gln91, known as the hypervariable region in $2 \mathrm{~S}$ albumins ${ }^{26-28}$, because of the high variability in length and sequence composition as shown in Fig. 6(1A). The scattering amplitudes of EsNap processed by PRIMUSQT were compared to the predicted 3D model of EsNap using the program CRYSOL, as shown in Fig. 6B with a calculated minimized $\chi^{2}-$ value of 1.87 . The manual superimposition well confirms the conclusion that the structures are widely similar, including the molecular weight comparison with the ab initio model. Lys 9, Arg 11, Lys 12 (blue) and Lys 105 (red) residues form flexible $\mathrm{N}$ and C-terminal of Es Nap ab initio model are as shown in Fig. 6B. These residues are involved in the antifungal and anticancer activity of $E s$ Nap. The in silico model of $E s$ Nap was aligned with the 
A

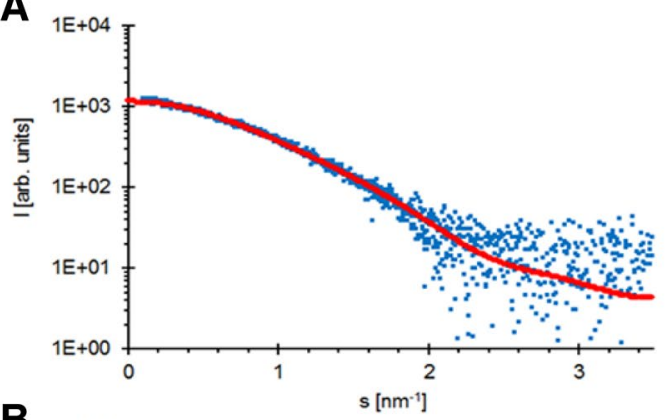

B

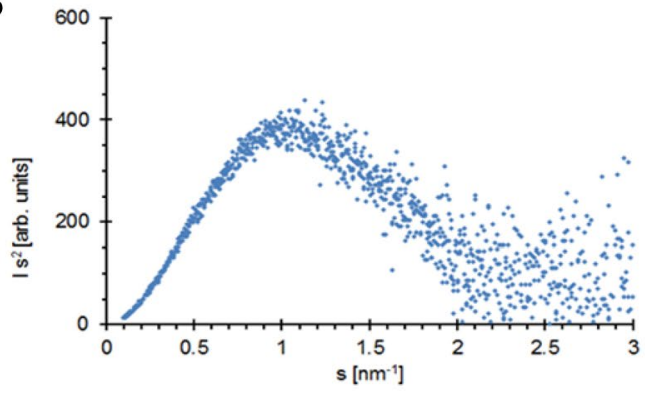

C

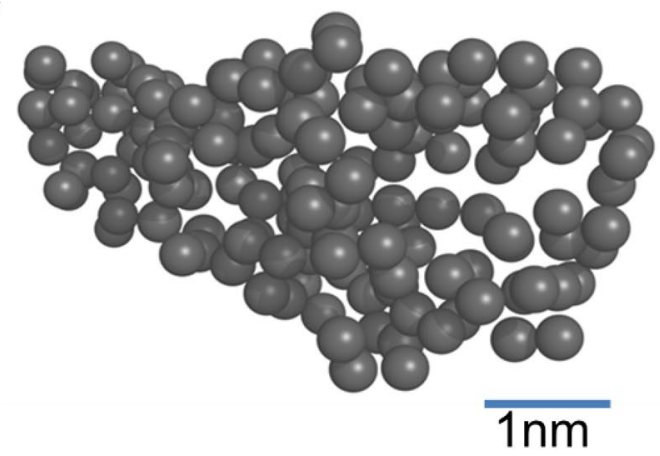

Figure 5. (A) Small-angle X-ray scattering intensity plot of pure EsNap and the corresponding calculated fit curve (red) resembling a single ab initio model as displayed in panel $\mathrm{C}$ and calculated by GASBOR. The plot shows the dependency of the scattering intensity I on the momentum transfers. (B) Kratky plot of the scattering intensity distribution indicating a compact and relatively rigid protein structure $(\mathbf{C}) \mathrm{Ab}$ initio model possessing P1 symmetry; the scale bar is $1 \mathrm{~nm}$ in length.

NMR structure of the pronapin precursor, BnIb from Brassica napus (PDB-ID: 1SM7) and crystal structure of 2S albumin from Moringa oleifera (PDB ID: 5DOM) and the respective RMSD values only for the carbon alpha (109) superposition are $0.89 \AA$ and $3.37 \AA$ respectively (Fig. 6C). The lower RMSD value was observed with the recombinant pronapin structure, which showed that the EsNap structure is structurally highly similar to the pronapin precursor from Brassica napus. The high RMSD value was obtained for $2 \mathrm{~S}$ albumin from M. oleifera due to presence of a significant variable loop in the form of antiparallel small $\beta$ sheet in $E s$ Nap $3 \mathrm{D}$ structure marked by red circle and other loop areas (Fig. 6A).

Antifungal activity. An antifungal activity of EsNap was observed against Fusarium graminearum as shown in Fig. 7A. All EsNap concentrations of 30, 50, and $100 \mu \mathrm{g}$ inhibited the fungal mycelia; growth after $96 \mathrm{~h}$ of incubation however, 50 and $100 \mu \mathrm{g}$ EsNap exhibited 50\% inhibition of the mycelia growth after $96 \mathrm{~h}$ (Fig. S3: Supplementary material). BSA was provided as an alternative protein nutrition source for comparison. There was significant inhibition of conidia germination with the $100 \mu \mathrm{g} E s \mathrm{Nap}$ in gene frame experiment as shown in Fig. 7B. The conidia germinate over night at $26^{\circ} \mathrm{C}$ and were imaged the next morning.

Cell cytotoxicity assessment. The number of living cells is represented by the absorbance of soluble formazan in the visible light spectrum ${ }^{29}$. The cytotoxic effect is shown in Fig. 8. Assessment of ell viability of Huh-7 cells against different dose concentrations by MTT assay. The results are expressed as mean \pm SD $(n=3)$. ${ }_{* * * *} P<0.0001$ is observed at doses of 25 and $50 \mu \mathrm{M}$. The $\mathrm{IC}_{50}$ value of EsNap was $20.49 \mu \mathrm{M}$ calculated by nonlinear regression analysis (Fig. S4: Supplementary material). 
$1 \mathrm{~A}$

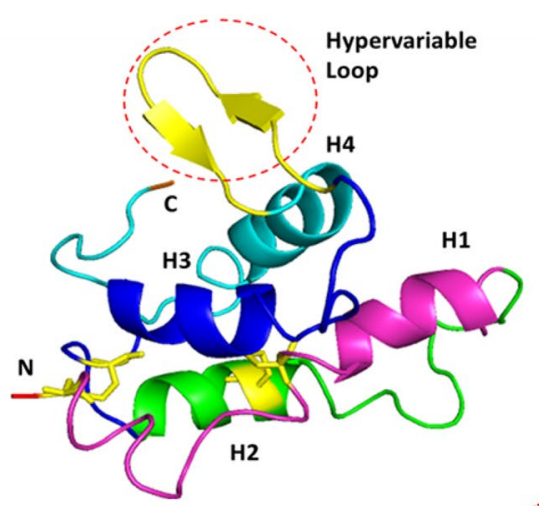

$2 A$

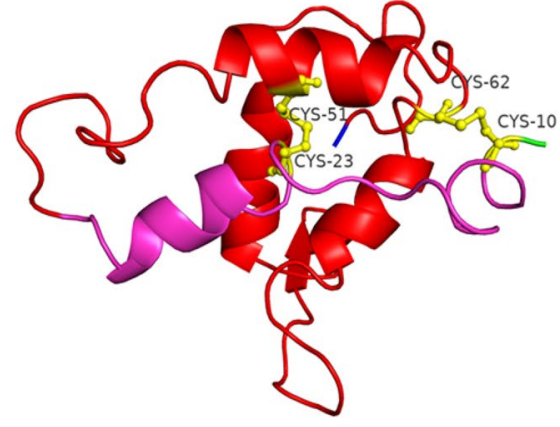

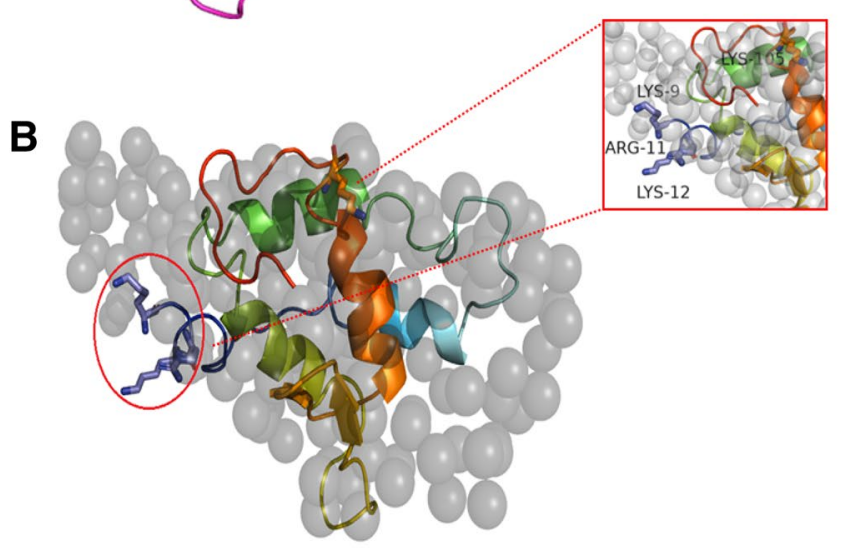

C

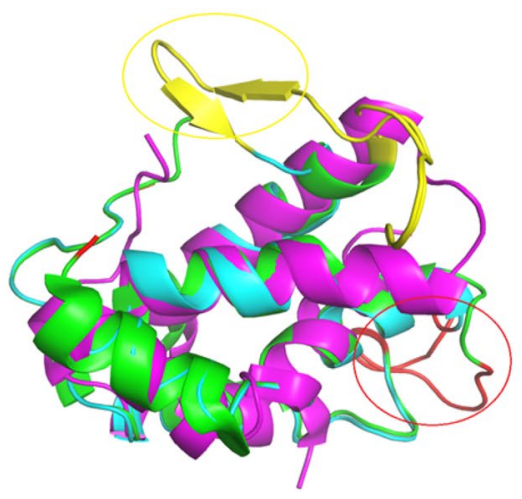

Figure 6. Overall structure of EsNap in-silico model and structural alignments. (1A) The 3D structure was predicted by homology modelling and is shown as ribbon diagram. The 3D model of EsNap consisted of four helices and a hypervariable loop comprising of two antiparallel $\beta$-sheets (yellow color) marked by red circle. (2A)The smaller chain composed of N-terminal (green) to $\mathrm{H} 1$ helix (purple) and longer composed of $\mathrm{H} 2, \mathrm{H} 3$, $\mathrm{H} 4$ and two short $\beta$-sheets (red). The disulfide bridges are represented by yellow spheres (B) Ab initio model of EsNap with P1 symmetry (grey spheres), Lys 9, Arg 11, Lys 12 (blue) and Lys 105 (red) form flexible $\mathrm{N}$ and C-terminal of ab initio model and 3D model of EsNap have been superimposed; involved in antifungal and anticancer activity. (C) Structural alignment of E. sativa napin (Cyan, EsNap) with BnIb from Brassica napus (Green, pdb code: 1SM7) and 2S albumin from Moringa oleifera (Purple, pdb code: 5DOM). Hypervariable loops and connecting loops between two polypeptide domains are colored in yellow and red, respectively.

Entomotoxicity assessment. Purified EsNap significantly inhibited the development of T. castaneum populations at all stages. Different biological traits i.e. number of larvae, male and female pupae including adults and total population were monitored. Results clearly revealed the effectiveness of the napin flour mixture when fed to T. castaneum. The results obtained at all protein concentrations are highly significant when compared to the control. The highest larval population was observed in the control group, i.e. $130.8 \pm 10.0$ with no napin provided, while it is obvious that all protein concentrations reduced the number of larvae significantly $(P<0.0006, \mathrm{~F}=9.96)$ (Table 1). Similarly, the total numbers of counted pupae and adults were strongly reduced at all concentrations of $E s$ Nap and a maximum was recorded in the control with no EsNap treatment (86.6 \pm 10.5 and $41.0 \pm 8.0)(P<0.0, F=22.5)$. In parallel, average larval, pupal and adults populations were decreased with increasing concentration, which means the smallest populations were observed at $3 \mathrm{mg} / \mathrm{ml}$ concentration followed by $2 \mathrm{mg} / \mathrm{ml}$ and $1 \mathrm{mg} / \mathrm{ml}$ of $E s \mathrm{Nap}$. The ratio of male and female pupae as well as adults was also recorded; 


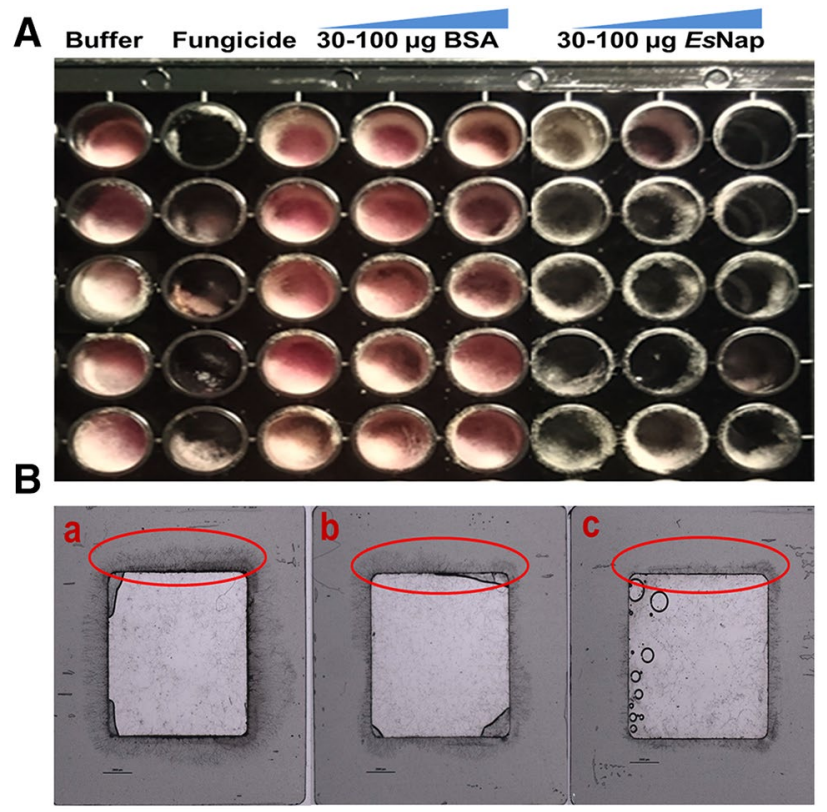

Figure 7. Inhibitory activities of EsNap towards growth of Fusarium graminearum mycelia. (A) All the three EsNap concentrations $(30,50$ and $100 \mu \mathrm{g}$ ) in medium inhibited the fungal growth, while regular and optimal fungal growth was observed in medium mixed with buffer and 30-100 $\mu \mathrm{g}$ BSA as well as only in buffer as negative control. No fungal growth was observed in the medium with fungicide TOPSIN as positive control. (B) Inhibition of mycelia growth of Fusarium graminearum in gene frame chamber. [a: BSA $(100 \mu \mathrm{g})$; b: phosphate buffer; c: Concentrated EsNap protein $(100 \mu \mathrm{g})]$.

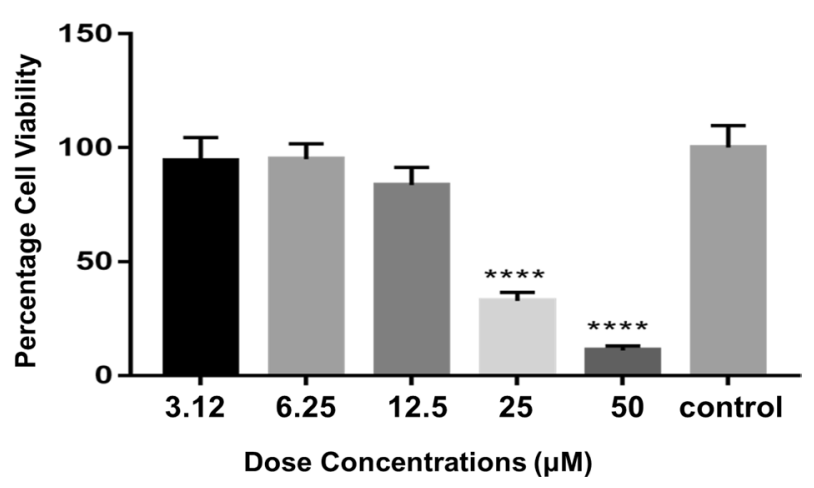

Figure 8. Effect of different doses of EsNap on Huh-7 cells visualized by plotting the protein concentration $(\mu \mathrm{M})$ against the cell viability (\%). Asterisks are indicating significant mycelia inhibition at concentrations of 25 and $50 \mu \mathrm{M}$; however, calculated $\mathrm{IC}_{50}$ value of EsNap was $20.49 \mu \mathrm{M}$.

\begin{tabular}{|l|c|l|l|l|l|l|l|}
\hline Concentration & Total larvae & Male pupae & Female pupae & Total pupae & Male adults & Female adults & Total adults \\
\hline $3 \mathrm{mg} / \mathrm{ml}$ & $39.4 \pm 2.1 \mathrm{c}$ & $10.8 \pm 1.5 \mathrm{c}$ & $9.4 \pm 1.8 \mathrm{~b}$ & $22.2 \pm 1.2 \mathrm{c}$ & $4.8 \pm 1.2 \mathrm{c}$ & $4.6 \pm 0.7 \mathrm{~b}$ & $9.4 \pm 1.9 \mathrm{~b}$ \\
\hline $2 \mathrm{mg} / \mathrm{ml}$ & $47.0 \pm 1.6 \mathrm{~b}$ & $13.0 \pm 4.0 \mathrm{~b}$ & $9.4 \pm 3.0 \mathrm{~b}$ & $22.0 \pm 3.2 \mathrm{c}$ & $6.4 \pm 0.7 \mathrm{~b}$ & $5.0 \pm 0.4 \mathrm{~b}$ & $11.4 \pm 0.9 \mathrm{~b}$ \\
\hline $1 \mathrm{mg} / \mathrm{ml}$ & $51.8 \pm 2.5 \mathrm{~b}$ & $14.4 \pm 2.2 \mathrm{~b}$ & $10.4 \pm 2.0 \mathrm{~b}$ & $28.8 \pm 2.8 \mathrm{~b}$ & $7.4 \pm 0.4 \mathrm{~b}$ & $6.2 \pm 0.6 \mathrm{~b}$ & $13.6 \pm 1.4 \mathrm{~b}$ \\
\hline Negative control & $130.8 \pm 10.0 \mathrm{a}$ & $45.6 \pm 4.2 \mathrm{a}$ & $41.0 \pm 7.0 \mathrm{a}$ & $86.6 \pm 10.5 \mathrm{a}$ & $23.4 \pm 3.8 \mathrm{a}$ & $17.6 \pm 4.7 \mathrm{a}$ & $41.0 \pm 8.0 \mathrm{a}$ \\
\hline
\end{tabular}

Table 2. Survival of T. castaneum in the presence of different EsNap concentrations. Least significant differences at the $1 \%$ probability level $(P<0.01)$. 
the male population was significantly larger in number as compared to the female population for all EsNap concentrations (Table 2).

\section{Discussion}

Napins are present in leaves, seeds, roots and stems of a number of plant species belonging to cereals and crucifers. Napins are synthesized as larger precursors, which have a post-translational N-terminal signal peptide and a C-terminal precursor peptide. Napin from the seeds of Taramira (Eruca sativa), a member of the family Brassicaceae, has been isolated and characterized. Eruca sativa napin (EsNap) has a molecular mass of around $16 \mathrm{kDa}$, as determined by SDS-PAGE. Most of the napins known today have molecular masses in the range of $16 \mathrm{kDa}$ and showed relatively high levels of sequence similarity. Napins are polypeptides containing S-S bonds that are formed under reducing conditions. Four S-S bonds existed in native napin structures, two between the chains and two within the larger chain ${ }^{30-32}$. Napin family is typically rich in arginine, lysine, and cysteine residues and have a strong antimicrobial activity ${ }^{33}$. Es Nap protein has basic properties due to high level of arginine and lysine compared to other amino acids. The IEF of EsNap showed the pI value of approximately 8.00. In 1981, Crouch and Sussex indicated that napins have basic pI of 11 which is verified due to high number of arginine, lysine and histidine residues ${ }^{34}$.

CD showed that EsNap has highly helical secondary structure content. In this context, Sharma et al. ${ }^{35}$ reported that 2 S Albumin (napin) from seeds of Wrightia tinctoria has a high content of $\alpha$-helices. Previous studies have reported $40-45 \%$ helices and $16-20 \% \beta$-sheets, $25 \% \alpha$-helix and 38\% $\beta$-sheets for napin. The high content of $\alpha$-helix in napins may promote some toxic biological activities against pathogens and facilitate the dynamic association of the protein with membranes, as summarized for some peptides by Bechinger ${ }^{36}$. Additional structural information about EsNap was obtained by SAXS analysis which strongly indicated that EsNap is globular with slightly elongated native form in solution and exists in a monomeric state. The shape factor, $R_{\mathrm{g}}$ divided by $R_{\mathrm{H}}$ as determined by DLS, has a value of 0.8 , which is indicative for a globular and slightly elongated shape of EsNap particles in agreement with the displayed ab initio model shown in Fig. 5C. N and C-terminal basic residues (Lysine and Arginine) of EsNap protein formed the flexible part of ab initio model in Fig. 6B and responsible for antifungal and anticancer activity in EsNap due to the distribution of cationic charge.

EsNap 3D structure has a-helix dominant secondary element as well as possesses high lysine and arginine contents and these properties together are responsible for antifungal and anti-cancerous activities. It has already been reported that an amphipathic conformation and high cationic charge distribution are responsible for antifungal activity of napins ${ }^{37}$. EsNap 3D structure showed strong amphipathic behavior parallel to their high lysine and arginine content, and thus fully comply with these two requirements. Amphipathic a-helix structure of EsNap may be involved in the CaM (Calmodulin) antagonist and formation of pores in membranes. This is probably because CaM and two subunits of $E s$ Nap contain similar a-helical conformations. Neumann and his colleagues reported that amphipathic $\alpha$-helix structure of napins showed the CaM (Calmodulin) antagonist activity and may be involved in development of membranous pores ${ }^{38}$.

EsNap exhibited antifungal activity against Fusarium graminearum at 30-100 $\mu$ g quantity. Initially, (48-72 h) as shown in figure $\mathrm{S}$, the fungal growth was promoted by the napin protein itself which is presumably due to the fact that the fungus partly metabolized the protein and used it as a carbon or nitrogen nutrition source. It is well known that nitrogen is an essential requirement for growth, and the ability to metabolize a wide variety of nitrogen sources enables fungi to colonize different environmental niches and survive nutrient limitations ${ }^{39}$. However, later on 96-120 h, napin-treated samples showed a significant reduction in growth compared to BSAtreated-samples (Fig. S4). Tomar and his colleagues reported that pumpkin 2 S albumin inhibited the growth of Fusarium oxysporum, Phanerochaete chrysosporium and Aspergillus flavus grown in PDA medium at 50 and $100 \mu \mathrm{g}$ protein dissolved in a similar culture volume ${ }^{40}$. Napin (PR protein-13) from Pennisetum glaucum (pearl millet) inhibited the growth of Sclerospora graminicola spores at a quantity of $100 \mu \mathrm{g}^{41}$. Wheat puronapins showed antifungal activity against Rhizoctonia solani by membrane permeabilization, responsible for significant crop losses and rice sheath blight ${ }^{42}$.

Plant napins are cytotoxic and have shown anti-cancerous activities. EsNap showed the cytotoxic activity against the Huh7 cells. EsNap concentrations of 25 and $50 \mu \mathrm{M}$ showed the significantly killing of cancerous cells and IC50 was obtained at $20.49 \mu \mathrm{M}$ by non-linear regression as shown in the Fig. 8. EsNap could be potential candidate for the development and formation of anticancer drug. Structural information of these proteins can be utilized for the design of new anticancer drugs. The $2 \mathrm{~S}$ albumin from seeds of pumkin showed the cytotoxicity against the breast cancer cell line MCF-7, ovarian teratocarcinoma cell line PA-1, prostate cancer cell line PC-3 and DU-145 and liver hepatocellular carcinoma (Hep G2) (Tomar et al., 2014). Different concentrations of this protein $(1,5,10,20,30$ and $40 \mu \mathrm{M})$, were used against cell lines. In response to $20 \mu \mathrm{M}$ of protein, the cell viabilities of breast cancer (MCF-7), ovarian teratocarcinoma (PA-1), prostate cancer (PC-3 and DU-145) and hepatocellular carcinoma (Hep G2) by treatment were found to be $43.40 \%, 54.81 \%, 49.12 \%, 43.3 \%$ and $45.69 \%$ respectively ${ }^{40}$.

Due to the alarming situation regarding the impact of conventional insecticides on human health and the surroundings, the search for novel molecules with insecticidal activity with minimal adverse effects has become paramount ${ }^{43}$. Purified $E s$ Nap produced strong negative effects on all life stages of stored grain insect pest $T$. castaneum. The plant extracted protein PAlb from Pisum sativum was first reported to act against stored grain insect pests especially on cereal weevils and was found to be a valuable naturally occurring biopesticide ${ }^{44,45}$. Many toxic metabolites with antimicrobial activity released by plants are currently commercially available as they also show an individual level of toxicity towards insect pests. Consequently, entomo-toxic plant compounds are an appreciated starting point to further develop bio-insecticides against stored product insect pests ${ }^{46}$ on a long-term scale after carefully verifying their respective persistency and toxicity spectrum. Muench et al. ${ }^{47}$, characterized pea 
albumin PA1b and mapped its binding site on insect vacuolar ATPase. Its interaction is influencing the toxicity and a similar mechanism is conceivable in case of napins resulting in reduced T. castaneum populations, as also observed by Da Silva and his group in 2012. The saponin 3-GlcA-28-AraRhaxyl-medicagenate from Medicago truncatula seeds due to its high toxicity against Sitophilus oryzae (Da Silva., 2012). This 3-GlcA-28-AraRhaxylmedicagenate exhibits repellent properties and has a CMC of about $0.6 \mathrm{mM}$. The exposed protein treatment to the insect is actually $0.4 \mathrm{mg} / \mathrm{g}$ of the flour which is not that high and review of literature supports our treatment values. However, there could be many reasons for toxicity of napins against T. castaneum as described previously $y^{47-50}$. Experiments applying napin of Pyrularia, which is hemolytic, cytotoxic and neurotoxic, suggest that negatively charged membrane lipids are targeted directly by conserved basic amino acids ${ }^{51}$. Consequently, it is concluded that napins commonly do not possess receptor specificity but induce the formation of oligomeric protein-lipid complexes and ion permeable membrane pores ${ }^{52,53}$. This mechanism would target a broad spectrum of species and is in agreement with the observed toxicity of EsNap towards the species that were selected for this study. Nonetheless, an improved understanding of the structure-function relationship and mode of action is essential for understanding the ecological mechanisms promoted by plant napins as well as utilizing napins for more biotechnological and medical applications.

\section{Experimental}

Plant material. Fresh seeds of Eruca sativa were obtained from Botanical garden; Bahauddin Zakariya University, Multan. Eruca sativa seeds were identified morphologically (color and shape) by the Department of Plant Protection, Government of Pakistan, Multan. It have been confirmed that the experimental samples of plants, including the collection of plant material, complied with relevant institutional, national, and international guidelines and legislation with appropriate permissions from the Department of Plant Protection, Government of Pakistan, Multan for collection of plant specimens.

Purification of napin. Seeds ( $5 \mathrm{~g}$ ) of E. sativa were ground by mortar and pestle to a powder form. The powder was homogenized in $100 \mathrm{ml}$ of $100 \mathrm{mM}$ phosphate buffer (pH 7.0) containing $1 \mathrm{mM}$ phenylmethylsulfonyl fluoride (PMSF) as protease inhibitor. The mixture was stirred continuously for three hours at $25^{\circ} \mathrm{C}$. After stirring, the sample was centrifuged (Ogawa 6470) at 10,000×g for $30 \mathrm{~min}$ and the pellet was discarded. The supernatant was filtered through Whatman filter paper (pore size $8 \mu \mathrm{m}$; EW-06648-46) to remove any particulate matter. The clear crude extract $(90 \mathrm{ml}$ ) was subjected to 50 (supernatant) and $70 \%$ ammonium sulfate precipitation by stepwise slow addition of salt with constant stirring using a magnetic stirrer at $4{ }^{\circ} \mathrm{C}$. The precipitated proteins were separated at low centrifugation speed of $3000 \mathrm{rpm}$ for $4 \mathrm{~min}$. The supernatant was removed and the resulting pellet was re-dissolved in $10 \mathrm{ml}$ of the same phosphate buffer and dialyzed thoroughly in $100 \mathrm{mM}$ phosphate buffer ( $\mathrm{pH} 7.0$ ) at $4{ }^{\circ} \mathrm{C}$ with gentle stirring. The desalted napin was further purified by injecting the solution onto a pre-equilibrated Hi Load 16/60 Superdex 200 column (GE Healthcare, ÄKTA prime plus). The protein was eluted with the same phosphate buffer at a flow rate of $1.0 \mathrm{ml} / \mathrm{min}$. Absorbance of the eluents was recorded at a wavelength of $280 \mathrm{~nm}$. The fractions with maximum protein content were analyzed and combined after running of $15 \%$ SDS-PAGE (E-VS10-SYS, omniPAGE mini-System, Germany) ${ }^{54}$. The concentration of purified protein was quantified by Nanodrop 2000c (Thermo Scientific, peqLab, Germany).

Mass spectrometric analysis. Gel bands stained with colloidal Coomassie were cut out and reduced and alkylated with DTT ( $10 \mathrm{mM}, 56{ }^{\circ} \mathrm{C}, 30 \mathrm{~min}$.) and Iodoacetamide (IAA, $55 \mathrm{Mm}$, room temperature in dark), respectively. The protein in the gel was digested with trypsin (conditions: $5 \mathrm{ng}$ trypsin/ $\mu$ l (sequencing grade modified trypsin, Promega, Madison, USA) in $50 \mathrm{mM} \mathrm{NH}_{4} \mathrm{HCO}_{3}, 37^{\circ} \mathrm{C}, 16 \mathrm{~h}$ ). After digestion, the gel pieces were repeatedly extracted ( $65 \%$ acetonitrile $/ 5 \%$ formic acid) the combined extracts were dried in a vacuum concentrator and redissolved in $20 \mu \mathrm{l} 0.1 \%$ formic acid. LC-MS/MS measurements were performed by injecting the samples into a nano liquid chromatography system (Dionex UltiMate 3000) coupled via electrospray-ionization (ESI) to an orbitrap mass spectrometer (Orbitrap Fusion, Thermo Scientific, Bremen, Germany). The samples were loaded $(3 \mu \mathrm{l} / \mathrm{min}$ ) onto a trapping column (Acclaim PepMap $\mu$-precolumn, C18; buffer A: $0.1 \%$ formic acid in $\mathrm{H} 2 \mathrm{O}$; buffer B: $0.1 \%$ formic acid in acetonitrile) with $2 \%$ buffer B, washed for 5 min with $2 \%$ buffer B $(3 \mu \mathrm{l} / \mathrm{min})$ and the peptides were eluted $(300 \mathrm{nl} / \mathrm{min}$ ) onto the separation column (Acclaim PepMap 100, C18, $75 \mu \mathrm{m} \times 250 \mathrm{~mm}$, gradient: $2-30 \%$ B in $35 \mathrm{~min}$ ). Mass spectrometric analysis was performed in positive ion mode. LC-MS/MS analysis was carried out in data dependent acquisition mode (DDA). MS ions were detected in orbitrap at $120 \mathrm{k}$ resolution while MS/MS spectra were recorded in the ion trap as detector.

LC-MS raw data were processed with Proteome Discoverer 2.0 (Thermo Scientific, Bremen, Germany). For identification, MS/MS spectra were searched with Sequest HT against the Arabidopsis and the plant Uniprot database (https://www.uniprot.org, downloaded November 10, 2019). The searches were performed using the following parameters: precursor mass tolerance $10 \mathrm{ppm}$, fragment mass tolerance $0.5 \mathrm{Da}$, two missed cleavages allowed, carbamidomethylation of cysteine residues as fixed modification, oxidation of methionine residues as a variable modification. Identifications were validated manually.

Protein identification. For protein identification, a search for sequence similarities was performed applying a BLAST tool through feeding of residual sequences https://www.uniprot.org/blast. Homologous sequences were subsequently aligned using ClustalW https://www.genome.jp/tools-bin/clustalw in the default set up and BoxShade server https://embnet.vital-it.ch/software/BOX_form.html.

Isoelectric focusing (IEF). IEF was performed using $17 \mathrm{~cm}$ long and $0.5 \mathrm{~mm}$ thick gel strips (pH 3-10, Sigma). Purified protein $(405 \mu \mathrm{g})$ was loaded onto the horizontal gel maintained at $28^{\circ} \mathrm{C}$ in dehydration buffer 
containing $8 \mathrm{M}$ urea, 2\% CHAPS, $50 \mathrm{mM}$ DTT, 0.2\% Bio-Lyte ampholytes and $0.001 \%$ bromophenol blue overnight. The $\mathrm{pI}$ markers proteins (Sigma) ranging from 3 to 10 were co-electrophoresed to estimate the $\mathrm{pI}$ of the proteins under investigation. Isoelectric focusing was performed in an IEF focusing cell (Bio-Rad). The voltage was increased stepwise starting from $250 \mathrm{~V}$ for $20 \mathrm{~min}, 10,000 \mathrm{~V}$ for $2.5 \mathrm{~h}$ and $10,000 \mathrm{~V}$ for $12 \mathrm{~h}$. The gels were maintained at $28^{\circ} \mathrm{C}$ during the run. After IEF, the proteins were stained by Coomassie blue.

Circular dichroism (CD) spectroscopy. CD spectroscopy experiments were performed to determine the secondary structure composition of napin applying a CD6 dichrograph instrument (Jobin Yvon, Longjumeau, France). Purified napin $(0.2 \mathrm{mg} / \mathrm{ml})$ was prepared in $25 \mathrm{mM}$ phosphate buffer, $\mathrm{pH} 7.0$ and the CD spectra of napin were recorded in the far-UV-range between 190 and $260 \mathrm{~nm}$ at $25^{\circ} \mathrm{C}$ in a $1 \mathrm{~mm}$ path length quartz cell. A total of fifteen spectra were averaged after measuring the buffer separately. The percentage of secondary structure of napin was calculated by using Spectra manager ${ }^{\mathrm{Tm}}$ software (Jasco).

Dynamic light scattering (DLS). Purified protein was analyzed by DLS using the SpectroLight 300 instrument (Xtal Concept, Germany) for confirming the monodispersity of the protein solution as well as the size distribution calculation of molecules.

Small-angle X-ray scattering (SAXS). Small-angle X-ray scattering data of napin at two different solution concentrations $(3.2$ and $6.5 \mathrm{mg} / \mathrm{ml})$ were collected at EMBL beamline P12 $2^{55}$ at the storage ring PETRA III (DESY, Hamburg, Germany). At a sample-detector distance of $3.0 \mathrm{~m}$ and a wavelength of $\lambda=0.124 \mathrm{~nm}$, scattering data were collected applying a 2D photon-counting Pilatus $2 \mathrm{M}$ pixel detector (Dectris) with the momentum transfer ranging from $0.03 \mathrm{~nm}^{-1}<s<4.80 \mathrm{~nm}^{-1}(s=4 \pi \sin \theta / \lambda$, where $2 \theta$ is the scattering angle). To exclude significant radiation damage, 20 successive X-ray exposures of napin of $45 \mathrm{~ms}$ each were compared and no significant changes in the intensity pattern were observed over time. Data were normalized to the intensity of the transmitted beam and radially averaged. The scattering pattern of the buffer was subtracted, and the difference curves were scaled for protein concentration. The radius of gyration Rg along with the particle pair-distance distribution function $\mathrm{p}(\mathrm{r})$, which further provides the maximum dimension Dmax, were computed by the automated SAXS data analysis pipeline SASFLOW and verified via PRIMUS ${ }^{56}$. Low resolution $a b$ initio shapes of napin were generated based on the composite scattering curves applying the program GASBOR ${ }^{57}$. It uses an assembly of interconnected dummy residue spheres to generate a chain-like $a b$ initio protein model that fits the experimental scattering data. The molecular weight of EsNap was estimated by its excluded particle volume and further verified based on the forward scattering intensity of BSA ( $66 \mathrm{kDa} ; 5 \mathrm{mg} / \mathrm{ml}$ in $50 \mathrm{mM} \mathrm{HEPES} \mathrm{pH} \mathrm{7.5),}$ which was measured in addition to verify beamline operation.

Homology modeling and structure prediction. For the calculation of an EsNap homology model, fasta sequence of napin-3 from Brassica napus (UniProtKB ID: P80208) was consequently used for the 3D modeling of EsNap. Therefore, the primary sequence of napin-3 was subjected to model building via the SwissModel server ${ }^{58-60}$. The coordinate information of recombinant pronapin precursor, BnIb from B. napus (PDBID: 1SM7) was used as the most suitable template. The model was built based on the target-template alignment using ProMod $3^{61}$. Coordinates of fragments with a conserved sequence comparing the target and the template were copied from the template to the model. Insertions and deletions were remodeled using a fragment library and side chains were then rebuilt. Finally, the geometry of the resulting model is regularized by using a force field. The images of the predicted model were prepared applying PyMOL ${ }^{62}$.

Fusarium multi-well plate growth assay. The 96-well microtiter plate assay is a sensitive and fast method for large scale measurement of the inhibitory effect of antifungal substances in vitro. To determine the inhibitory impact of EsNap on the germination and growth of the fungus Fusarium graminearum, the hypha growth over a time period of $120 \mathrm{~h}$ was obtained at an incubation temperature of $26^{\circ} \mathrm{C}$. Each well of a Greiner 96-well flat bottom plate contained $100 \mu \mathrm{l}$ minimal medium ${ }^{63}, 4 \mu \mathrm{l}$ conidia suspension $\left(125\right.$ conidia $\mathrm{l}^{-1}$ ) of $F$. graminearum strain 8/1 $1^{64}$ constitutively expressing GFP as well as EsNap or BSA solution (30,50 and $100 \mu \mathrm{g}$ in corresponding wells) respectively in addition to buffer. Phosphate buffer $(50 \mathrm{ml}, 100 \mathrm{mM}, \mathrm{pH} 7.0)$ and fungicide TOPSIN $^{\oplus} 4.5 \mathrm{FL}(10 \mu \mathrm{L})$ both were used as positive and negative controls, respectively. Five technical replicates were done for all concentrations and controls while three measurements were done for each well every time. Fungal growth was observed after $48-72 \mathrm{~h}$ of incubation.

The germination rate of the conidia (F. graminearum) was checked in $125 \mu$ l gene frame chamber (Thermofisher, Catalog, AB0578). Gene frame chamber is perfect for standard microscope slides and they prevent reagent loss during the longer time series. Gene frame chamber contained the conidia in minimal media, EsNap protein $(100 \mu \mathrm{g})$, BSA $(100 \mu \mathrm{g})$ and phosphate buffer.

Cell cytotoxicity assay. The cell survival and proliferation MTT (3-(4, 5-dimethylthiazol-2-yl) -2, 5-diphenyl tetrazolium bromide) assay kit (Millipore, USA) was used for rapid and perceptive quantification of cell proliferation and viability. Briefly, $100 \mu \mathrm{l}\left(1 \times 10^{5}\right)$ of Huh7 cells were cultured in a 96 wells plate using the Dulbecco's modified Eagle medium (DMEM) supplemented with $10 \%$ fetal bovine serum and $100 \mathrm{IU} / \mathrm{ml}$ penicillin and $100 \mu \mathrm{g} / \mathrm{ml}$ streptomycin at $37^{\circ} \mathrm{C}$ in a $\mathrm{CO}_{2}$ incubator for $24 \mathrm{~h}$. Es Nap dilutions 3.12, 6.25, 12.5, 25 and $50 \mu \mathrm{M}$ were added and the plate was incubated at $37^{\circ} \mathrm{C}$ in a $\mathrm{CO}_{2}$ incubator for another $24 \mathrm{~h}$ and three replications were performed and analyzed for each dilution. After $24 \mathrm{~h}$ the medium was removed and $100 \mu \mathrm{l}$ freshly prepared medium was added along with $10 \mu \mathrm{l}$ MTT solution $(5 \mathrm{mg} / \mathrm{ml}$ in PBS) as per manufacturer's instructions. The 
plate was again incubated in a $\mathrm{CO}_{2}$ incubator at $37^{\circ} \mathrm{C}$ for $4 \mathrm{~h}$ and after this $0.1 \mathrm{ml}$ DMSO was added to dissolve the formazan crystals in the wells. Mitochondrial succinic dehydrogenase in living cells converts the MTT substance in purple formazan crystals that are insoluble in water. The MTT formazan product was detected by measuring the optical density with a multi-channel plate reading photometer at a test wavelength of $570 \mathrm{~nm}$ and a reference wavelength of $620 \mathrm{~nm}^{65}$. Cell viability was attained by means of the following formula:

$$
\begin{aligned}
\text { Cell viability }[\%]= & (\text { A_test }(570 \mathrm{~nm})-\text { A_test }(620 \mathrm{~nm}) /(\text { A_control }(570 \mathrm{~nm}) \\
& - \text { A_control }(620 \mathrm{~nm})) * 100 .
\end{aligned}
$$

The $\mathrm{IC}_{50}$ (50\% inhibitory concentration) value was calculated by non-linear regression analysis with GraphPad Prism software. The assay was conducted in triplicate. One way ANOVA was performed on data with a level of significance $P<0.05$.

Entomotoxicity assay. Entomotoxicity assays applying napin were performed in the Eco-toxicology laboratory, Faculty of Agriculture Sciences and Technology, Bahauddin Zakayria University Multan. Napin toxicity was determined for T. castaneum. A population of T. castaneum was collected from a local flour mill and was cultured on whole wheat flour with $5 \%$ brewer yeast $^{66}$. To get an equal age insect population, the culture medium was complete wheat flour incubated at $60-90^{\circ} \mathrm{C}$ for $60 \mathrm{~min}$. One glass jar was used and filled with $500 \mathrm{~g}$ flour and 50 red flour beetles were added. For the oviposition beetles were left in the culture medium. After three days beetles were removed with the help of sieves and then added to a separate set of sterilized jars filled with $200 \mathrm{~g}$ flour for maintenance of the culture. Flour containing eggs was used as culture medium for obtaining adult beetles of a homogenous population ${ }^{67,68}$. The culture was maintained under optimum laboratory conditions at $30{ }^{\circ} \mathrm{C}$ with a relative humidity of $70 \%$.

For the bioassays three different serial dilutions of napin were prepared in $100 \mathrm{mM}$ phosphate buffer and 3, 2 and $1 \mathrm{mg} / \mathrm{ml}$ protein concentrations were used. A total of $450 \mathrm{~g}$ of wheat flour was pre-refrigerated at $4{ }^{\circ} \mathrm{C}$ to avoid any infestation. Each protein concentration was prepared in $100 \mathrm{ml}$ buffer solution mixed with $150 \mathrm{~g}$ flour to form homogeneous dough. It was dried in the dark to form a hard pan and subsequently grinded with an electric grinder providing powder. Five replications using one fifth of the material each for all three concentrations and a control for comparison, i.e. buffer with no napin, were set up. Each replication was executed in an individual glass jar. Five males and five females of T. castaneum were released in each jar. After ten days, released adults were removed and interval data of larvae, male and female pupae including adults were recorded weekly.

Statistical analysis. The entomotoxin protein bioassay data were analyzed in one way ANOVA through the stat software "Statistix 8.1" and mean values were separated by a Tukey-HSD test with a level of significance of 0.05 (Analytical Software, 2005).

\section{Conclusions}

In conclusion, a napin protein was isolated and purified from Eruca sativa and contains disulfide bonds in a monomeric form. Furthermore, the napin inhibits the growth of F. graminearum at the stage of conidia and possesses cytotoxicity towards Huh7 cells. Based on its above-mentioned properties, different napins like EsNap may promote the resistance of plants against infections by parasitic fungi and likewise reduce the susceptibility towards other plant pathogens.

Received: 9 August 2021; Accepted: 1 November 2021

Published online: 15 December 2021

\section{References}

1. Deice Raasch-Fernandes, L. et al. Induction of phytoalexins and proteins related to pathogenesis in plants treated with extracts of cutaneous secretions of southern Amazonian Bufonidae amphibians. PLoS ONE 14, e0211020 (2019).

2. Deveau, A. et al. Bacterial-fungal interactions: Ecology, mechanisms and challenges. FEMS Microbiol. Rev. 42, 335-352 (2018).

3. Edqvist, J., Blomqvist, K., Nieuwland, J. \& Salminen, T. A. Plant lipid transfer proteins: Are we finally closing in on the roles of these enigmatic proteins?. J. Lipid Res. 59, 1374-1382 (2018).

4. Tam, J. P., Wang, S., Wong, K. H. \& Tan, W. L. Antimicrobial peptides from plants. Pharmaceuticals 8, 711-757 (2015).

5. Ishaq, N., Bilal, M. \& Iqbal, H. Medicinal potentialities of plant defensins: A review with applied perspectives. Medicines 6, 29 (2019).

6. Slavokhotova, A., Shelenkov, A., Andreev, Y. A. \& Odintsova, T. Hevein-like antimicrobial peptides of plants. Biochem. Mosc. 82, 1659-1674 (2017).

7. Tang, S.-S., Prodhan, Z. H., Biswas, S. K., Le, C.-F. \& Sekaran, S. D. Antimicrobial peptides from different plant sources: Isolation, characterisation, and purification. Phytochemistry 154, 94-105 (2018).

8. Holding, D. R. Recent advances in the study of prolamin storage protein organization and function. Front. Plant Sci. 5, 276 (2014).

9. Perera, S. P., McIntosh, T. C. \& Wanasundara, J. P. Structural properties of cruciferin and napin of Brassica napus (Canola) show distinct responses to changes in $\mathrm{pH}$ and temperature. Plants 5, 36 (2016).

10. Wanasundara, J. P., McIntosh, T. C., Perera, S. P., Withana-Gamage, T. S. \& Mitra, P. Canola/rapeseed protein-functionality and nutrition. OCl 23, D407 (2016).

11. Simoes, M., Bennett, R. N. \& Rosa, E. A. Understanding antimicrobial activities of phytochemicals against multidrug resistant bacteria and biofilms. Nat. Prod. Rep. 26, 746-757 (2009).

12. Stein, A. C., Sortino, M., Avancini, C., Zacchino, S. \& von Poser, G. Ethnoveterinary medicine in the search for antimicrobial agents: Antifungal activity of some species of Pterocaulon (Asteraceae). J. Ethnopharmacol. 99, 211-214 (2005).

13. Guzmán-Rodríguez, J. J., Ochoa-Zarzosa, A., López-Gómez, R. \& López-Meza, J. E. Plant antimicrobial peptides as potential anticancer agents. BioMed Res. Int. https://doi.org/10.1155/2015/735087 (2015). 
14. Pelegrini, P. B. \& Franco, O. L. Plant $\gamma$-thionins: Novel insights on the mechanism of action of a multi-functional class of defense proteins. Int. J. Biochem. Cell Biol. 37, 2239-2253 (2005).

15. Thomma, B. P., Cammue, B. P. \& Thevissen, K. Mode of action of plant defensins suggests therapeutic potential. Curr. Drug TargetsInfect. Disorders 3, 1-8 (2003).

16. Thomma, B. P., Cammue, B. P. \& Thevissen, K. Plant defensins. Planta 216, 193-202 (2002).

17. Jaafar, N. S. \& Jaafar, I. S. Eruca sativa Linn.: Pharmacognostical and pharmacological properties and pharmaceutical prepara-tions. Asian J. Pharm. Clin. Res. 12, 39-45 (2019).

18. Fuentes, E., Alarcón, M., Fuentes, M., Carrasco, G. \& Palomo, I. A novel role of Eruca sativa Mill.(rocket) extract: Antiplatelet (NF-kB Inhibition) and antithrombotic activities. Nutrients 6, 5839-5852 (2014).

19. Radziejewska-Kubzdela, E., Olejnik, A. \& Biegańska-Marecik, R. Effect of pretreatment on bioactive compounds in wild rocket juice. J. Food Sci. Technol. 56, 5234-5242 (2019).

20. Yehuda, H. et al. Isothiocyanates inhibit psoriasis-related proinflammatory factors in human skin. Inflamm. Res. 61, 735-742 (2012).

21. Bell, L. \& Wagstaff, C. Glucosinolates, myrosinase hydrolysis products, and flavonols found in rocket (Eruca sativa and Diplotaxis tenuifolia). J. Agric. Food Chem. 62, 4481-4492 (2014).

22. Manavalan, P. \& Johnson, W. C. Sensitivity of circular dichroism to protein tertiary structure class. Nature 305, 831-832 (1983).

23. Yang, J. T., Wu, C.-S.C. \& Martinez, H. M. Calculation of protein conformation from circular dichroism. In Methods in Enzymology Vol. 130 (eds Wilchek, M. \& Bayer, E. A.) 208-269 (Elsevier, Amsterdam, 1986).

24. Petoukhov, M. V. et al. New developments in the ATSAS program package for small-angle scattering data analysis. J. Appl. Crystal$\log$. 45, 342-350 (2012).

25. Pantoja-Uceda, D. et al. Solution structure and stability against digestion of rproBnIb, a recombinant $2 \mathrm{~S}$ albumin from rapeseed: Relationship to its allergenic properties. Biochemistry 43, 16036-16045 (2004).

26. Monsalve, R. I., Lopez-Otin, C., Villalba, M. \& Rodríguez, R. A new distinct group of $2 \mathrm{~S}$ albumins from rapeseed: Amino acid sequence of two low molecular weight napins. FEBS Lett. 295, 207-210 (1991).

27. Raynal, M., Depigny, D., Grellet, F. \& Delseny, M. Characterization and evolution of napin-encoding genes in radish and related crucifers. Gene 99, 77-86 (1991).

28. Krebbers, E. et al. Determination of the processing sites of an Arabidopsis $2 S$ albumin and characterization of the complete gene family. Plant Physiol. 87, 859-866 (1988).

29. Mosmann, T. Rapid colorimetric assay for cellular growth and survival: Application to proliferation and cytotoxicity assays. J. Immunol. Methods 65, 55-63 (1983).

30. Wanasundara, J. P. Proteins of Brassicaceae oilseeds and their potential as a plant protein source. Crit. Rev. Food Sci. Nutr. 51, 635-677 (2011).

31. Bérot, S., Compoint, J., Larré, C., Malabat, C. \& Guéguen, J. Large scale purification of rapeseed proteins (Brassica napus L.). J. Chromatogr. B 818, 35-42 (2005).

32. Aluko, R. E. \& McIntosh, T. Polypeptide profile and functional properties of defatted meals and protein isolates of canola seeds. J. Sci. Food Agric. 81, 391-396 (2001).

33. Charity, J. A. et al. Pest and disease protection conferred by expression of barley $\beta$-hordothionin and Nicotiana alata proteinase inhibitor genes in transgenic tobacco. Funct. Plant Biol. 32, 35-44 (2005).

34. Crouch, M. L. \& Sussex, I. M. Development and storage-protein synthesis in Brassica napus L. embryos in vivo and in vitro. Planta 153, 64-74 (1981).

35. Sharma, A. et al. Purification and Characterization of $2 \mathrm{~S}$ albumin from seeds of Wrightia tinctoria exhibiting antibacterial and DNase activity. Protein Peptide Lett. 24, 368-378 (2017).

36. Bechinger, B. Proteins Membrane Binding and Pore Formation 24-30 (Springer, Berlin, 2010).

37. Powers, J.-P.S. \& Hancock, R. E. The relationship between peptide structure and antibacterial activity. Peptides 24, 1681-1691 (2003).

38. Neumann, G. M., Condron, R., Thomas, I. \& Polya, G. M. Purification and sequencing of multiple forms of Brassica napus seed napin small chains that are calmodulin antagonists and substrates for plant calcium-dependent protein kinase. Biochimica Biophysica Acta (BBA)-Protein Struct. Mol. Enzymol. 1295, 23-33 (1996).

39. Tudzynski, B. Nitrogen regulation of fungal secondary metabolism in fungi. Front. Microbiol. 5, 656 (2014).

40. Tomar, P. P. S. et al. Characterization of anticancer, DNase and antifungal activity of pumpkin 2 S albumin. Biochem. Biophys. Res. Commun. 448, 349-354 (2014)

41. Chandrashekhara, Niranjan-Raj, S., Deepak, S., Manjunath, G. \& Shekar Shetty, H. Thionins (PR protein-13) mediate pearl millet downy mildew disease resistance. Arch. Phytopathol. Plant Protect. 43, 1356-1366 (2010).

42. Oard, S., Rush, M. \& Oard, J. Characterization of antimicrobial peptides against a US strain of the rice pathogen Rhizoctonia solani. J. Appl. Microbiol. 97, 169-180 (2004).

43. Da Silva, P. et al. High toxicity and specificity of the saponin 3-GlcA-28-AraRhaxyl-medicagenate, from Medicago truncatula seeds, for Sitophilus oryzae. BMC Chem. Biol. 12, 3 (2012).

44. Higgins, T. et al. Gene structure, protein structure, and regulation of the synthesis of a sulfur-rich protein in pea seeds. J. Biol. Chem. 261, 11124-11130 (1986).

45. Gressent, F., Da Silva, P., Eyraud, V., Karaki, L. \& Royer, C. Pea Albumin 1 subunit b (PAlb), a promising bioinsecticide of plant origin. Toxins 3, 1502-1517 (2011).

46. Bednarek, P. \& Osbourn, A. Plant-microbe interactions: Chemical diversity in plant defense. Science 324, 746-748 (2009).

47. Muench, S. P. et al. PAlb inhibitor binding to subunits $\mathrm{c}$ and e of the vacuolar ATPase reveals its insecticidal mechanism. J. Biol. Chem. 289, 16399-16408 (2014).

48. Rahioui, I. et al. Toxicity, binding and internalization of the pea-A1b entomotoxin in Sf9 cells. Biochimie 89, 1539-1543 (2007).

49. Jouvensal, L. et al. PA1b, an insecticidal protein extracted from pea seeds (Pisum sativum): 1H-2-D NMR study and molecular modeling. Biochemistry 42, 11915-11923 (2003).

50. Gressent, F., Rahioui, I. \& Rahbé, Y. Characterization of a high-affinity binding site for the pea albumin $1 \mathrm{~b}$ entomotoxin in the weevil Sitophilus. Eur. J. Biochem. 270, 2429-2435 (2003).

51. e Castro, V. O. \& Vernon, L. P. Hemolytic activity of thionin from Pyrularia pubera nuts and snake venom toxins of Naja naja species: Pyrularia thionin and snake venom cardiotoxin compete for the same membrane site. Toxicon 27, 511-517 (1989).

52. Hughes, P., Dennis, E., Whitecross, M., Llewellyn, D. \& Gage, P. The cytotoxic plant protein, $\beta$-purothionin, forms ion channels in lipid membranes. J. Biol. Chem. 275, 823-827 (2000).

53. Stec, B. et al. Proposal for molecular mechanism of thionins deduced from physico-chemical studies of plant toxins. Chem. Biol. Drug Des. 64, 210-224 (2004).

54. Laemmli, U. K. Cleavage of structural proteins during the assembly of the head of bacteriophage T4. Nature 227, 680-685 (1970).

55. Blanchet, C. E. et al. Versatile sample environments and automation for biological solution X-ray scattering experiments at the P12 beamline (PETRA III, DESY). J. Appl. Crystallogr. 48, 431-443 (2015).

56. Franke, D., Kikhney, A. G. \& Svergun, D. I. Automated acquisition and analysis of small angle X-ray scattering data. Nucl. Instrum. Methods Phys. Res. Sect. A: Accel. Spectrom. Detect. Assoc. Equip. 689, 52-59 (2012). 
57. Svergun, D. I., Petoukhov, M. V. \& Koch, M. H. Determination of domain structure of proteins from X-ray solution scattering. Biophys. J. 80, 2946-2953 (2001).

58. Arnold, K., Bordoli, L., Kopp, J. \& Schwede, T. The SWISS-MODEL workspace: A web-based environment for protein structure homology modelling. Bioinformatics 22, 195-201 (2006).

59. Biasini, M. et al. SWISS-MODEL: Modelling protein tertiary and quaternary structure using evolutionary information. Nucl. Acids Res. 42, W252-W258 (2014).

60. Guex, N. \& Peitsch, M. C. SWISS-MODEL and the Swiss-Pdb Viewer: An environment for comparative protein modeling. Electrophoresis 18, 2714-2723 (1997).

61. Benkert, P., Biasini, M. \& Schwede, T. Toward the estimation of the absolute quality of individual protein structure models. Bioinformatics 27, 343-350 (2011).

62. DeLano, W. The PyMOL Molecular Graphics System, Version 1.2 r3pre, Schrödinger, LLC. There is no corresponding record for this reference (2002).

63. Leach, J., Lang, B. \& Yoder, O. Methods for selection of mutants and in vitro culture of Cochliobolus heterostrophus. Microbiology 128, 1719-1729 (1982).

64. Trail, F. \& Common, R. Perithecial development by Gibberella zeae: A light microscopy study. Mycologia 92, 130-138 (2000).

65. Rehman, S., Ashfaq, U. A., Riaz, S., Javed, T. \& Riazuddin, S. Antiviral activity of Acacia nilotica against Hepatitis C Virus in liver infected cells. Virology journal 8, 220 (2011).

66. Khalequzzaman, M., Khatun, M. \& Talukdar, D. Growth of Tribolium confusum Duv. on wheat flour with various yeast levels. Int. Pest Control 36, 128-130 (1994).

67. Saleem, M. Toxicological studies on synthetic pyrethroid against red flour beetle Tribolium castaneum (Herbst.)(Coleoptera: Tenebrionidae), Ph.D. Thesis University of Punjab (1990).

68. Sial, M., Saeed, Q., Rahman, S. \& Qayyum, M. Upshot of food add-ons on the life history and development of Tribolium castaneum (Herbst)(Coleoptera: Tenebrionidae). Afr. Entomol. 25, 37-42 (2017).

\section{Acknowledgements}

This research has been supported by the Higher Education Commission (HEC) of Pakistan as a part of awarding an IRSIP scholarship and also by the European Molecular Biology Laboratory, Hamburg, and Germany through kind support in small angle X-ray scattering data collection at the EMBL beamline P12.

\section{Author contributions}

Conceptualization of the research project was performed by A.A. while B.K., S.F., C.B. is responsible for the experimental design, data collection and prepared the manuscript. A.A. performed the mass spectrometry, M.B. provided the cell toxicity analysis and G.B. did the antifungal analysis. A.M. and Q.S. processed and analyzed the data. H.U.R.A., A.M., Q.A. and S.M. reviewed the manuscript.

\section{Competing interests}

The authors declare no competing interests.

\section{Additional information}

Supplementary Information The online version contains supplementary material available at https://doi.org/ 10.1038/s41598-021-02174-6.

Correspondence and requests for materials should be addressed to Q.A. or A.A.

Reprints and permissions information is available at www.nature.com/reprints.

Publisher's note Springer Nature remains neutral with regard to jurisdictional claims in published maps and institutional affiliations.

(c) (i) Open Access This article is licensed under a Creative Commons Attribution 4.0 International License, which permits use, sharing, adaptation, distribution and reproduction in any medium or format, as long as you give appropriate credit to the original author(s) and the source, provide a link to the Creative Commons licence, and indicate if changes were made. The images or other third party material in this article are included in the article's Creative Commons licence, unless indicated otherwise in a credit line to the material. If material is not included in the article's Creative Commons licence and your intended use is not permitted by statutory regulation or exceeds the permitted use, you will need to obtain permission directly from the copyright holder. To view a copy of this licence, visit http://creativecommons.org/licenses/by/4.0/.

(c) The Author(s) 2021 